\title{
Association of vitamin $D$ receptor Taql and Apal genetic polymorphisms with nephrolithiasis and end stage renal disease: a meta-analysis
}

\author{
Tajamul Hussain ${ }^{1 *}$ (D), Shaik M. Naushad ${ }^{2}$, Anwar Ahmed ${ }^{1}$, Salman Alamery ${ }^{1,3}$, Arif A. Mohammed ${ }^{1}$, \\ Mohamed O. Abdelkader ${ }^{3}$ and Nasser Abobakr Nasser Alkhrm ${ }^{3}$
}

\begin{abstract}
Background: The deficiency of vitamin D receptor (VDR) or its ligand, vitamin D3, is linked to the development of renal diseases. The Taql (rs731236) and Apal (rs7975232) polymorphisms of VDR gene are widely studied for their association with renal disease risk. However, studies have largely been ambiguous.

Methods: Meta-analysis was carried out to clarify the association of Taql (2777 cases and 3522 controls) and Apal (2440 cases and 3279 controls) polymorphisms with nephrolithiasis (NL), diabetic nephropathy (DN) and end stage renal disease (ESRD).

Results: The VDR Taql C-allele under allele contrast was significantly associated with ESRD in both fixed effect and random effect models, and Apal C-allele with ESRD only under fixed effect model. Cochrane Q-test showed no evidence of heterogeneity for Taql polymorphism and a significant heterogeneity for Apa I polymorphism. No publication bias was observed for both the polymorphisms.
\end{abstract}

Conclusions: The present meta-analysis identifies Taql and Apal polymorphisms of VDR gene as risk factors for renal diseases.

Keywords: Vitamin D receptor gene polymorphism, End stage renal disease, Nephrolithiasis, Diabetic nephropathy, Meta-analysis

\section{Introduction}

In human skin, solar rays facilitate the formation of vitamin D3 from 7-dehydrocholesterol. The vitamin D3 undergoes two-step hydroxylation to form 25-hydroxy vitamin D3 (25-OHD3) and biologically active 1,25dihydroxyvitamin D3 $\left(1,25-(\mathrm{OH})_{2} \mathrm{D} 3\right)$ [1]. Vitamin D receptor (VDR) is a ligand-activated transcriptional factor requiring $1,25(\mathrm{OH}) 2 \mathrm{D}$ for its activation [2]. The deficiency of 25OHD or VDR is reported to activate renin-angiotensin system resulting in high angiotensin II levels, which damage renal parenchyma leading to

\footnotetext{
* Correspondence: thussain@ksu.edu.sa

${ }^{1}$ Center of Excellence in Biotechnology Research, Department of Biochemistry, College of Science Building 5, King Saud University, Riyadh 11451, Saudi Arabia

Full list of author information is available at the end of the article
}

increased risk for renal disease [3]. Considering the pivotal role of VDR in maintaining normal renal function, a number of studies have explored the possibility of association of VDR gene polymorphisms with renal disease risk. Among VDR polymorphisms reported to date, ApaI, and TaqI are widely studied for their association with ESRD, NL and DN [4-6]. The ApaI variant (rs7975232), which results in A to $C$ transition, is located in the intron 8 of VDR gene, while TaqI variant (rs731236), which results in $\mathrm{T}$ to $\mathrm{C}$ transition is located in exon 9 [7].

The rs7975232 (NG_008731.1:g.64978G > T) is an intronic variant predicted to influence splice site changes that might affect the translation of VDR. The frequency of this variant is high as evidenced by 734 and 16,751 homozygous mutants in 1000G and ExAC databases.

(c) The Author(s). 2019 Open Access This article is distributed under the terms of the Creative Commons Attribution 4.0 International License (http://creativecommons.org/licenses/by/4.0/), which permits unrestricted use, distribution, and reproduction in any medium, provided you give appropriate credit to the original author(s) and the source, provide a link to the Creative Commons license, and indicate if changes were made. The Creative Commons Public Domain Dedication waiver (http://creativecommons.org/publicdomain/zero/1.0/) applies to the data made available in this article, unless otherwise stated. 


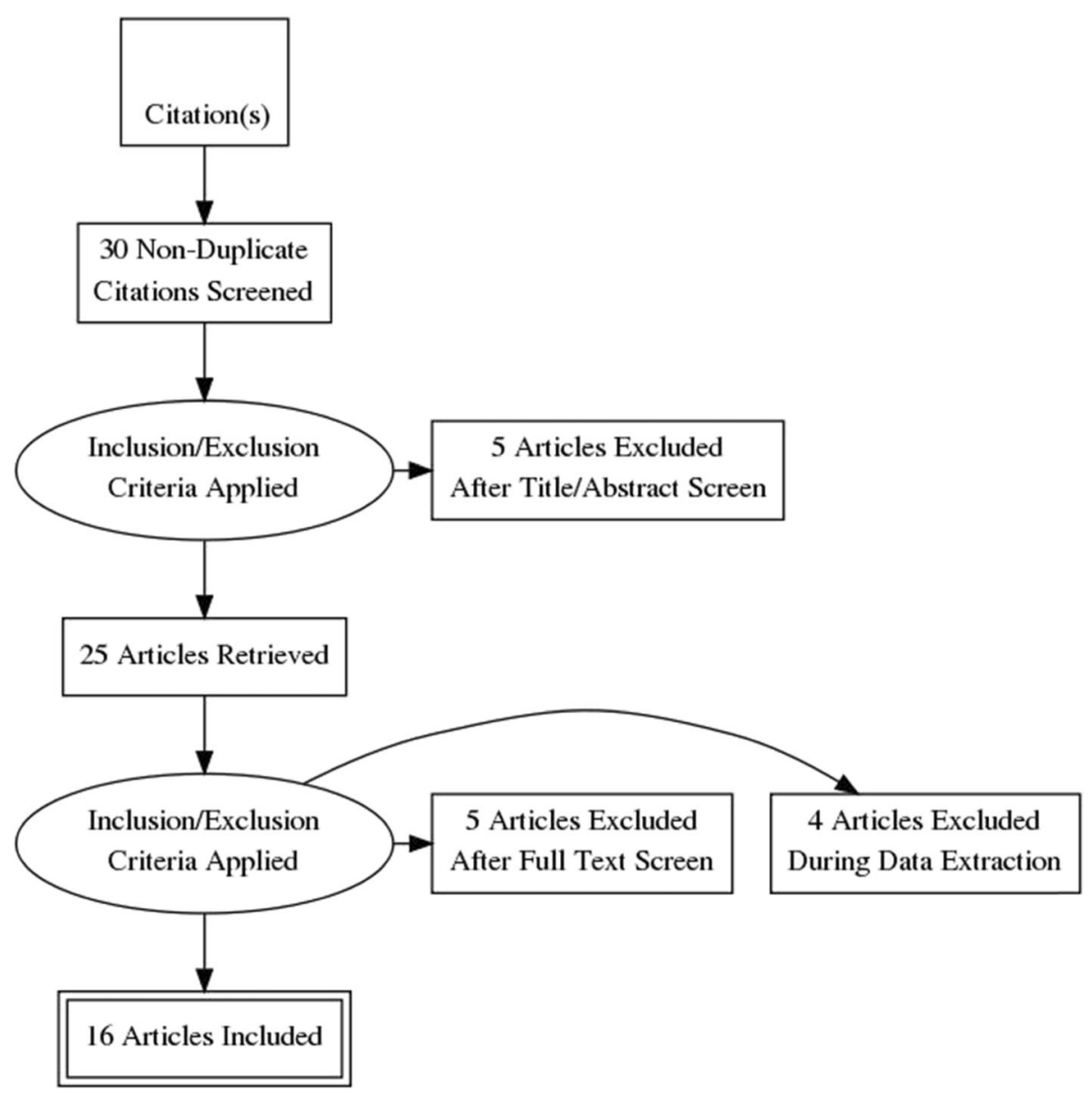

Fig. 1 PRISMA flowchart showing the steps in meta-analysis data extraction

The rs731236 (NG_008731.1:g.65058 T > C) variant is near the exon-intron boundary (GCTG/attg) and hence likely to influence splicing and thus might affect the translation of VDR. The frequency of this variant is lower than that of rs7975232 with 242 and 7505 homozygous mutants identified in 1000G and ExAC databases.

Importantly, genetic studies examining the role of TakI and ApaI polymorphisms in the pathogeneses of NL, DN and ESRD remained ambiguous [4-6, 812]. Considering the significance of VDR signaling in the protection against renal diseases and the ambiguity in the studies relating VDR gene polymorphism with the disease etiology, present meta-analysis comprising 2669 renal disease cases and 3342 controls was carried out to clarify the association of VDR gene TaqI and ApaI polymorphisms with nephrolithiasis, ESRD and diabetic nephropathy.

\section{Methods}

Data extraction

The literature retrieval was carried out using keywords: vitamin $\mathrm{D}$ receptor or VDR, renal disease, nephrolithiasis or urolithiasis, diabetic nephropathy, TaqI (rs731236) and ApaI (rs7975232) in PubMed, Medline and google scholar databases. All the free full texts were retrieved and wherever full text was not available, reprint request was sent to the corresponding author of the respective article. The criteria to include in the meta-analysis were: 1) availability of full text of the article, 2) inclusion of studies involving both cases and controls (either online or through reprint from the corresponding author), 3) availability of raw data on genotypes, and 4) restricting to studies published in only English language. The information related to each study such as first author, year of study, ethnic group or population studied, distribution of genotypes in cases and controls etc. was computed. The decision on the studies to be included in meta-analysis was taken by all the authors of this study.

\section{Meta-analysis}

The data computed in four columns wherein first two columns represent the number of variant alleles 
Table 1 Distribution of VDR1 Taql polymorphism in different case-control studies

\begin{tabular}{|c|c|c|c|c|c|c|c|c|c|c|c|}
\hline \multirow[t]{3}{*}{ Author } & \multirow[t]{3}{*}{ Year } & \multirow[t]{3}{*}{ Country } & \multirow{3}{*}{$\begin{array}{l}\text { Renal } \\
\text { disease } \\
\text { type }\end{array}$} & \multicolumn{6}{|c|}{ Genotypes } & \multirow{2}{*}{\multicolumn{2}{|c|}{ C-allele frequency }} \\
\hline & & & & \multicolumn{3}{|c|}{ Cases } & \multicolumn{3}{|c|}{ Control } & & \\
\hline & & & & $\bar{\pi}$ & TC & $\mathrm{CC}$ & $\overline{T T}$ & $\mathrm{TC}$ & CC & Cases & Contro \\
\hline Wang [23] & 2016 & China & ESRD & 215 & 197 & 40 & 474 & 358 & 72 & 0.31 & 0.28 \\
\hline Cakir [20] & 2016 & Turkey & $\mathrm{NL}$ & 35 & 44 & 19 & 31 & 29 & 10 & 0.42 & 0.35 \\
\hline Guha [13] & 2015 & India & $\mathrm{NL}$ & 58 & 82 & 60 & 65 & 58 & 77 & 0.51 & 0.53 \\
\hline Martin [24] & 2010 & Ireland & DN & 225 & 327 & 103 & 249 & 327 & 98 & 0.41 & 0.39 \\
\hline Ozkaya [16] & 2003 & Turkey & $\mathrm{NL}$ & 33 & 27 & 4 & 50 & 30 & 10 & 0.27 & 0.28 \\
\hline Mossetti [25] & 2003 & Italy & $\mathrm{NL}$ & 80 & 104 & 36 & 35 & 66 & 13 & 0.40 & 0.40 \\
\hline Bucan [27] & 2009 & Croatia & DN & 5 & 6 & 3 & 13 & 14 & 6 & 0.43 & 0.39 \\
\hline Nosratabadi [7] & 2010 & Iran & DN & 9 & 55 & 36 & 4 & 63 & 33 & 0.64 & 0.65 \\
\hline Goknar [15] & 2016 & Turkey & $\mathrm{NL}$ & 25 & 41 & 12 & 14 & 43 & 3 & 0.42 & 0.41 \\
\hline Tripathi [21] & 2010 & India & ESRD & 105 & 115 & 38 & 267 & 228 & 74 & 0.37 & 0.33 \\
\hline Mittal [22] & 2010 & India & $\mathrm{NL}$ & 56 & 61 & 8 & 84 & 50 & 16 & 0.31 & 0.27 \\
\hline Moyano [26] & 2007 & Spain & $\mathrm{NL}$ & 15 & 23 & 13 & 9 & 11 & 1 & 0.48 & 0.31 \\
\hline Gunes [17] & 2006 & Turkey & $\mathrm{NL}$ & 37 & 63 & 10 & 61 & 73 & 16 & 0.38 & 0.35 \\
\hline Seyhan [18] & 2007 & Turkey & $\mathrm{NL}$ & 27 & 35 & 18 & 13 & 25 & 2 & 0.44 & 0.36 \\
\hline Aykan [19] & 2015 & Turkey & $\mathrm{NL}$ & 67 & 61 & 36 & 66 & 86 & 15 & 0.41 & 0.35 \\
\hline Han [14] & 2015 & China & $\mathrm{NL}$ & 102 & 6 & 0 & 160 & 16 & 4 & 0.03 & 0.07 \\
\hline
\end{tabular}

The following studies were shown to have deviation from HWE: Guha et al. $(p<0.0001)$, Nosratabadi et al. ( $p=0.0008)$, Goknar et al. ( $p=0.0008)$ and Han et al. $(p=0.0008)$

ESRD end stage renal disease, $N L$ nephrolithiasis, $D N$ diabetic nephropathy

in cases and controls and last two columns represent the number of ancestral alleles in cases and controls. Log (odds ratio) or effect size and standard error (SE) are calculated based on these four column data. Based on these two parameters, variance $\left(\mathrm{SE}^{2}\right)$, weight and 95\% confidence interval of effect size were calculated. Cochrane $\mathrm{Q}$ test and $\mathrm{I}^{2}$ statistics were performed to test the heterogeneity in the association. The plot of $1 / \mathrm{SE}$ and Z-statistics was also used as an index to test heterogeneity. The publication bias was based on the rank correlation of SE and $v$. The fixed effect and random effect models were generated based on Mantel Haenszel and DerSimonian Lair's methods, respectively. If no evidence of heterogeneity was found, fixed effect model was considered. If test heterogeneity was significant, random effect model was considered.

\section{Results}

Figure 1 depicts the data extraction process for the meta-analysis. Of the 16 case-control studies retrieved on the association of TaqI polymorphism with renal disease (Table 1), four studies showed deviation from Hardy-Weinberg equilibrium [7, 13-15]. Among the different population groups included in this metaanalysis, the largest being that of Turkish representing five case-control studies [16-20], two studies from India $[21,22]$ and one each from China [23], Ireland [24], Italy [25], Spain [26] and Croatia [27]. In total, the final metaanalysis was based on the data of 2777 cases and 3522 controls representing 16 case-control studies.

Cochrane Q-test (Q: 13.72, $p=0.54)$ and $\mathrm{I}^{2}(0.00)$ statistics showed no evidence of heterogeneity in association. Egger's test revealed no evidence of publication bias $(p=0.14)$. The VDR TaqI C-allele, under allele contrast fixed effect model, was associated with renal diseases calculated collectively for DN, ESRD and NL (OR: $1.11,95 \%$ CI: $1.03-1.20, p=0.008$ ). (Figure 2) As shown Table 2, subtype analysis revealed Taql C-allele to be associated with ESRD (OR: 1.17, 95\% CI: $1.02-$ 1.34, $p=0.03$ ) (Fig. 2). Among the different ethnic groups, Turkish population showed strong association between VDR TaqI polymorphism and renal disease in allele contrast model (C vs. T, OR: 1.19, 95\% CI: 1.01$1.42, p=0.04)$. Sensitivity analysis revealed that omitting either of the studies had no effect on overall outcome of disease risk.

Of the 13 case-control studies (2440 cases and 3279 controls) retrieved on the association of ApaI polymorphism with renal disease (Table 3), five studies deviated from Hardy-Weinberg equilibrium [7, 15, 19, $21,28]$. Among the studies in accordance with HWE 


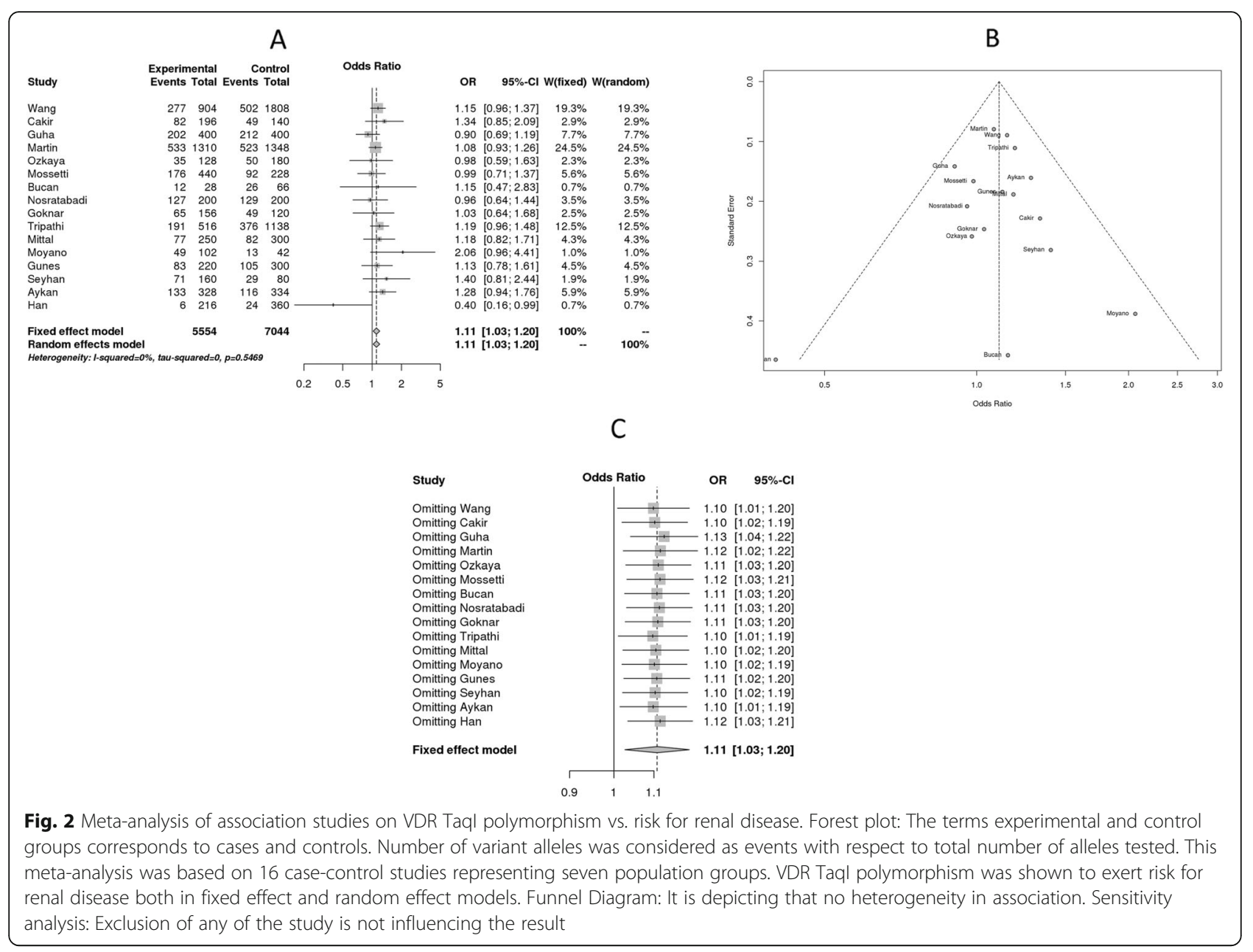

equilibrium, 3 studies were from Turkey [16, 17, 20], two from China [14, 23], and one each from Ireland [24] and Iran [29]. Cochrane Q-test (Q: 17.01, $p=0.03$ ) and $\mathrm{I}^{2}$ (48.3) statistics showed high-degree of heterogeneity in association. Egger's test revealed no evidence of publication bias $(p=0.54)$. The fixed effect model showed positive association of VDR ApaI polymorphism with all the renal disease cases (C vs. A, OR: 1.10, 95\% CI: 1.01-1.19), whereas, random effect model showed null association (OR: 1.05, 95\% CI: 0.93-1.19) (Fig. 3). Sensitivity analysis for ApaI polymorphism revealed that the sources of heterogeneity are two studies i.e. Wang et al. and Tripathi et al. However, overall trend suggests ApaI variant as a risk factor for renal disease. As shown in Table 4, subgroup analysis revealed association of VDR ApaI polymorphism with ESRD (C vs. A, OR: 1.31, 95\% CI: 1.15$1.50, p=0.0001)$ and no association with NL and DN.

\section{Discussion}

Deficiency of vitamin D or defective activation of VDR by its ligand, 1,25-dihydroxy vitamin $\mathrm{D}$ results in secondary hyperparathyroidism, angiotensin II-mediated renal damage and renal disease pathogenesis [3]. On the other hand, VDR activation suppressed inflammatory cell infiltration and inhibited nuclear factor- $\mathrm{kB}$ activation [30]. Likewise, active vitamin D3 and lentivirus-mediated transforming growth factor- $\beta$ (TGF- $\beta$ ) interference effectively reduced renal fibrosis in rat models [31]. These observations highlight the importance of VDR signaling in maintaining normal renal function. Accordingly, a number of studies have investigated the effects of polymorphisms in VDR gene on renal disease etiology. Among these, TaqI, and ApaI polymorphisms are widely studied [4-6]. However, there is a considerable ambiguity among these genetic studies, possibly stemming from sample size, ethnicity or gene-environmental interactions [4-6, 8-12]. To clarify whether TaqI and apaI polymorphisms have a role in renal disease pathogenesis, this meta-analysis comprising 2777 renal disease cases including DN, NL and ESRD and 3522 healthy controls was carried out. The present metaanalysis revealed an increased disease risk for subjects harboring TaqI C-allele under fixed and random effect models. Subgroup analysis based on type 
Table 2 Subgroup analysis showing disease-specific risk with VDR Taql polymorphism

\begin{tabular}{|c|c|c|c|c|c|}
\hline Model & Type of disease & $\mathrm{N}$ & OR & $95 \% \mathrm{Cl}$ & $P$ value \\
\hline \multirow[t]{4}{*}{ Allele contrast (A vs. a) } & Overall & 16 & 1.11 & {$[1.0262 ; 1.1967]$} & 0.009 \\
\hline & ESRD & 2 & 1.17 & {$[1.0171 ; 1.3357]$} & 0.028 \\
\hline & $\mathrm{NL}$ & 11 & 1.09 & {$[0.9673 ; 1.2356]$} & 0.153 \\
\hline & DN & 3 & 1.07 & {$[0.9250 ; 1.2322]$} & 0.371 \\
\hline \multirow[t]{4}{*}{ Recessive model (AA vs. Aa+aa) } & Overall & 16 & 1.19 & {$[0.9266 ; 1.5392]$} & 0.170 \\
\hline & ESRD & 2 & 1.14 & {$[0.8497 ; 1.5235]$} & 0.386 \\
\hline & $\mathrm{NL}$ & 11 & 1.32 & {$[0.8084 ; 2.1503]$} & 0.268 \\
\hline & DN & 3 & 1.11 & {$[0.8527 ; 1.4432]$} & 0.439 \\
\hline \multirow[t]{4}{*}{ Dominant model (AA+Aa vs. aa) } & Overall & 16 & 1.14 & {$[1.0234 ; 1.2709]$} & 0.017 \\
\hline & ESRD & 2 & 1.24 & {$[1.0367 ; 1.4863]$} & 0.019 \\
\hline & $\mathrm{NL}$ & 11 & 1.09 & {$[0.9148 ; 1.2930]$} & 0.342 \\
\hline & DN & 3 & 1.09 & {$[0.8737 ; 1.3505]$} & 0.456 \\
\hline \multirow[t]{4}{*}{ Overdominant (Aa vs. AA + aa) } & Overall & 16 & 0.99 & {$[0.8106 ; 1.2040]$} & 0.904 \\
\hline & ESRD & 2 & 1.19 & {$[0.9904 ; 1.4233]$} & 0.063 \\
\hline & $\mathrm{NL}$ & 11 & 0.92 & {$[0.6575 ; 1.2975]$} & 0.647 \\
\hline & DN & 3 & 1.01 & {$[0.8261 ; 1.2289]$} & 0.940 \\
\hline \multirow[t]{4}{*}{ pairw1 (AA vs. aa) } & Overall & 16 & 1.20 & {$[1.0117 ; 1.4232]$} & 0.036 \\
\hline & ESRD & 2 & 1.26 & {$[0.9280 ; 1.7151]$} & 0.138 \\
\hline & $\mathrm{NL}$ & 11 & 1.23 & {$[0.9346 ; 1.6077]$} & 0.141 \\
\hline & DN & 3 & 1.11 & {$[0.8081 ; 1.5149]$} & 0.528 \\
\hline \multirow[t]{4}{*}{ pairw2 (AA vs. Aa) } & Overall & 16 & 1.16 & {$[0.8525 ; 1.5857]$} & 0.341 \\
\hline & ESRD & 2 & 1.01 & {$[0.7443 ; 1.3803]$} & 0.932 \\
\hline & $\mathrm{NL}$ & 11 & 1.30 & {$[0.7200 ; 2.3483]$} & 0.384 \\
\hline & DN & 3 & 1.09 & {$[0.8304 ; 1.4407]$} & 0.524 \\
\hline \multirow[t]{4}{*}{ pairw3 (Aa vs. aa) } & Overall & 16 & 1.09 & {$[0.9167 ; 1.2888]$} & 0.337 \\
\hline & ESRD & 2 & 1.24 & {$[1.0233 ; 1.4966]$} & 0.028 \\
\hline & $\mathrm{NL}$ & 11 & 1.04 & {$[0.7873 ; 1.3666]$} & 0.795 \\
\hline & DN & 3 & 1.07 & {$[0.8487 ; 1.3425]$} & 0.577 \\
\hline
\end{tabular}

Table 3 Distribution of VDR1 Apal polymorphism across different case-controls studies

\begin{tabular}{|c|c|c|c|c|c|c|c|c|c|c|c|}
\hline \multirow[t]{3}{*}{ Author } & \multirow[t]{3}{*}{ Year } & \multirow[t]{3}{*}{ Country } & \multirow{3}{*}{$\begin{array}{l}\text { Renal } \\
\text { disease } \\
\text { type }\end{array}$} & \multicolumn{6}{|c|}{ Genotypes } & \multirow{2}{*}{\multicolumn{2}{|c|}{ C-allele frequency }} \\
\hline & & & & \multicolumn{3}{|c|}{ Cases } & \multicolumn{3}{|c|}{ Control } & & \\
\hline & & & & AA & $A C$ & CC & AA & $A C$ & CC & Cases & Controls \\
\hline Wang [23] & 2016 & China & ESRD & 206 & 207 & 39 & 502 & 350 & 52 & 0.32 & 0.25 \\
\hline Cakir [20] & 2016 & Turkey & $\mathrm{NL}$ & 43 & 40 & 15 & 26 & 34 & 10 & 0.36 & 0.39 \\
\hline Ghorbanihaghjo [29] & 2014 & Iran & $\mathrm{CH}$ & 10 & 23 & 13 & 16 & 16 & 11 & 0.53 & 0.44 \\
\hline Martin [24] & 2010 & Ireland & DN & 185 & 323 & 147 & 200 & 322 & 152 & 0.47 & 0.46 \\
\hline Ozkaya [16] & 2003 & Turkey & $\mathrm{NL}$ & 13 & 30 & 21 & 4 & 50 & 36 & 0.56 & 0.68 \\
\hline Zhang [28] & 2012 & China & DN & 19 & 89 & 74 & 11 & 65 & 46 & 0.65 & 0.64 \\
\hline Han [14] & 2015 & China & DN & 2 & 50 & 56 & 18 & 80 & 82 & 0.75 & 0.68 \\
\hline Nosratabadi [7] & 2010 & Iran & DN & 9 & 64 & 27 & 9 & 63 & 28 & 0.59 & 0.60 \\
\hline Goknar [15] & 2016 & Turkey & $\mathrm{NL}$ & 24 & 42 & 12 & 11 & 40 & 9 & 0.42 & 0.48 \\
\hline Tripathi [21] & 2010 & India & ESRD & 80 & 116 & 62 & 171 & 324 & 74 & 0.47 & 0.41 \\
\hline Mittal [22] & 2010 & India & $\mathrm{NL}$ & 43 & 70 & 12 & 57 & 71 & 22 & 0.38 & 0.38 \\
\hline Gunes [17] & 2006 & Turkey & $\mathrm{NL}$ & 40 & 58 & 12 & 59 & 72 & 19 & 0.37 & 0.37 \\
\hline Aykan [19] & 2015 & Turkey & $\mathrm{NL}$ & 14 & 5 & 145 & 12 & 0 & 155 & 0.90 & 0.93 \\
\hline
\end{tabular}

The following studies were shown to have deviation from HWE: Ozkaya et al. $(p=0.03)$, Nosratabadi et al. $(p=0.009)$, Goknar et al. ( $p=0.03)$, Tripathi et al. ( $p<$ $0.0001)$ and Aykan et al. $(p<0.0001)$

ESRD end stage renal disease, NL nephrolithiasis, $C H$ chronic hemodialysis, DN diabetic nephropathy 


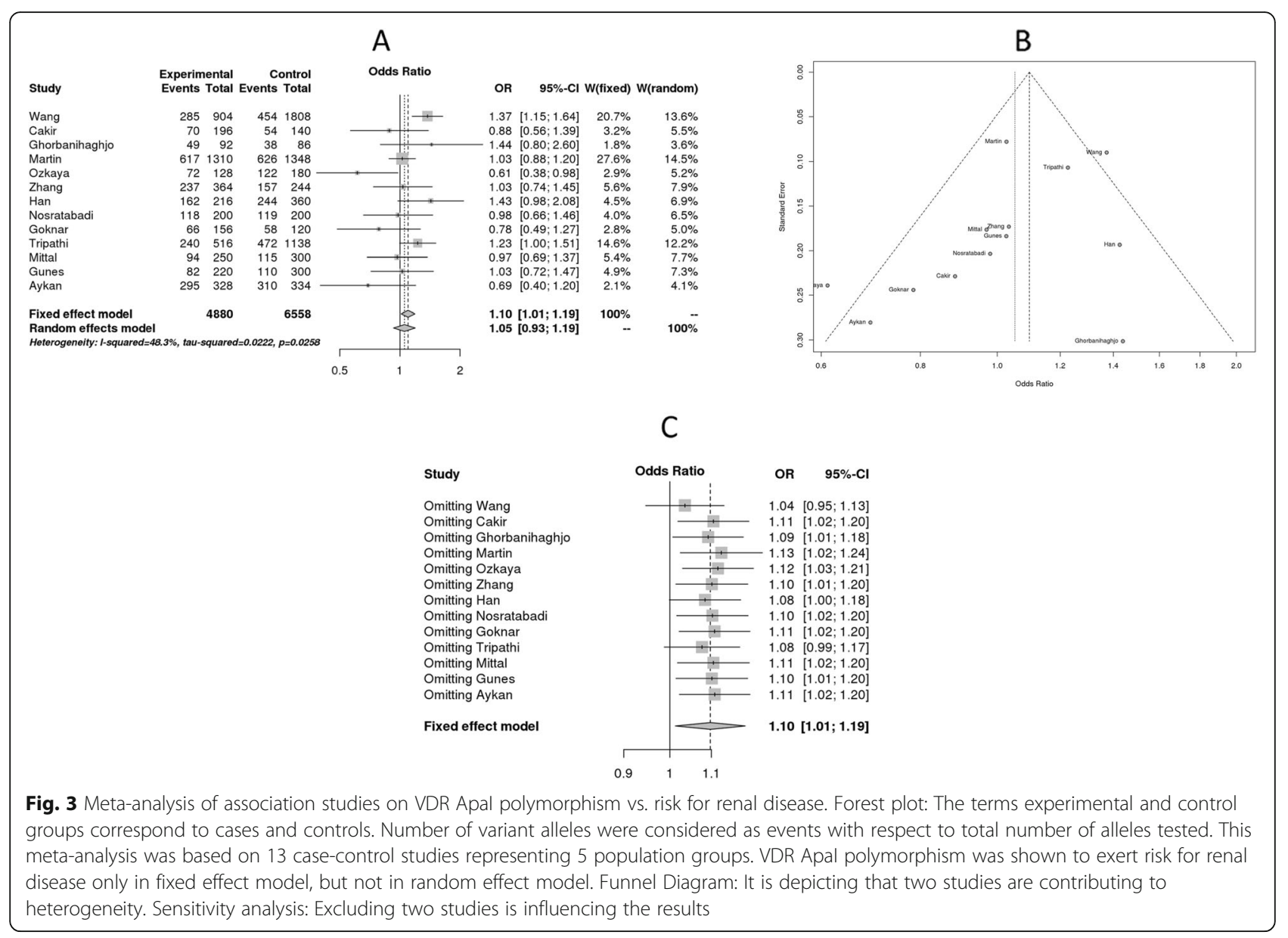

of renal disease showed that VDR TaqI polymorphism is associated with ESRD in allele contrast model, whereas no significant association was found between TaqI polymorphism and DN and NL. In the case of ApaI polymorphism, Apal C-allele was found to be linked to ESRD, but not with DM or NL under fixed effect model. Earlier, Yang et al. performed a meta-analysis on 1510 cases and 1812 controls and found no association of BsmI, FokI, TaqI, and ApaI polymorphisms of VDR with end-stage renal disease. Inclusion of more studies benefited the current meta-analysis.

The direct role of solar rays in the synthesis of vitamin D is well known. In human skin, solar rays facilitate the formation of vitamin D3 from 7-dehydrocholesterol, which is evident from the presence of higher mean serum vitamin $D$ levels in summer than in winter [32]. Likewise, higher vitamin D levels were found in populations living in regions known to have longer durations of sun exposure [33].

\section{Conclusions}

This meta-analysis revealed the association of VDR TaqI and ApaI polymorphisms with ESRD risk. This is the first meta-analysis study to simultaneously evaluate the association of DN, NL and ESRD with renal disease risk. Ethnicity, sample size, geneenvironmental interactions appear to be responsible for inconsistencies observed in the association studies examining VDR polymorphisms and renal diseases. The limitations of this meta-analysis include; exclusion of studies where raw data or full text were not accessible and one-to-one correlation between vitamin D3 profile and risk could not be established as no parallel studies were conducted.

\section{Abbreviations}

1,25 $(\mathrm{OH})_{2}$ D3: 1,25-dihydroxyvitamin D3; 25-OHD3: 25-hydroxy vitamin D3; DN: diabetic nephropathy; ESRD: end stage renal disease; NL: nephrolithiasis; VDR: vitamin D receptor

\section{Acknowledgments}

Not applicable

\section{Author's contribution}

TH conceived the study, participated in data analysis and manuscript writing, SMN participated in data analysis and manuscript writing, AA participated in data analysis, SA participated in data compilation and manuscript writing. AAM participated in data analysis and manuscript writing, MOA participated in data analysis. NANA participated in data compilation and manuscript writing. All authors have read and approved the manuscript. 
Table 4 Subgroup analysis showing disease-specific risk with VDR Apal polymorphism

\begin{tabular}{|c|c|c|c|c|c|}
\hline Model & Type of disease & N & OR & $95 \% \mathrm{Cl}$ & $\mathrm{p}$-val \\
\hline \multirow[t]{5}{*}{ Allele contrast (A vs. a) } & Overall & 13 & 1.05 & {$[0.9282 ; 1.1931]$} & 0.4259 \\
\hline & ESRD & 2 & 1.31 & {$[1.1454 ; 1.4996]$} & 0.0001 \\
\hline & $\mathrm{NL}$ & 6 & 0.86 & {$[0.7193 ; 1.0175]$} & 0.0777 \\
\hline & $\mathrm{CH}$ & 1 & 1.44 & {$[0.7974 ; 2.5983]$} & 0.2268 \\
\hline & DN & 4 & 1.06 & {$[0.9361 ; 1.1997]$} & 0.3589 \\
\hline \multirow[t]{5}{*}{ Recessive model (AA vs. Aa+aa) } & Overall & 13 & 1.10 & {$[0.8891 ; 1.3548]$} & 0.3865 \\
\hline & ESRD & 2 & 1.85 & {$[1.3925 ; 2.4544]$} & 0.0000 \\
\hline & $\mathrm{NL}$ & 6 & 0.77 & {$[0.5591 ; 1.0553]$} & 0.1035 \\
\hline & $\mathrm{CH}$ & 1 & 1.15 & {$[0.4482 ; 2.9300]$} & 0.7760 \\
\hline & DN & 4 & 1.06 & {$[0.8695 ; 1.2818]$} & 0.5840 \\
\hline \multirow[t]{5}{*}{ Dominant model (AA+Aa vs. aa) } & Overall & 13 & 1.03 & {$[0.8131 ; 1.3008]$} & 0.8153 \\
\hline & ESRD & 2 & 1.21 & {$[0.7844 ; 1.8716]$} & 0.3868 \\
\hline & $\mathrm{NL}$ & 6 & 0.76 & {$[0.5034 ; 1.1586]$} & 0.2049 \\
\hline & $\mathrm{CH}$ & 1 & 2.13 & {$[0.8380 ; 5.4311]$} & 0.1120 \\
\hline & DN & 4 & 1.09 & {$[0.8749 ; 1.3545]$} & 0.4466 \\
\hline \multirow[t]{5}{*}{ Overdominant (Aa vs. AA + aa) } & Overall & 13 & 0.99 & {$[0.8143 ; 1.2066]$} & 0.9300 \\
\hline & ESRD & 2 & 0.91 & {$[0.4290 ; 1.9490]$} & 0.8167 \\
\hline & $\mathrm{NL}$ & 6 & 0.96 & {$[0.6559 ; 1.3933]$} & 0.8147 \\
\hline & $\mathrm{CH}$ & 1 & 1.69 & {$[0.7239 ; 3.9340]$} & 0.2256 \\
\hline & DN & 4 & 1.03 & {$[0.8660 ; 1.2221]$} & 0.7472 \\
\hline \multirow[t]{5}{*}{ pairw1 (AA vs. aa) } & Overall & 13 & 1.09 & {$[0.8006 ; 1.4779]$} & 0.5907 \\
\hline & ESRD & 2 & 1.81 & {$[1.3275 ; 2.4638]$} & 0.0002 \\
\hline & $\mathrm{NL}$ & 6 & 0.70 & {$[0.4803 ; 1.0158]$} & 0.0604 \\
\hline & $\mathrm{CH}$ & 1 & 1.89 & {$[0.6130 ; 5.8330]$} & 0.2677 \\
\hline & DN & 4 & 1.09 & {$[0.8307 ; 1.4252]$} & 0.5399 \\
\hline \multirow[t]{5}{*}{ pairw2 (AA vs. Aa) } & Overall & 13 & 1.10 & {$[0.8709 ; 1.3854]$} & 0.4280 \\
\hline & ESRD & 2 & 1.74 & {$[0.9540 ; 3.1683]$} & 0.0709 \\
\hline & $\mathrm{NL}$ & 6 & 0.86 & {$[0.5968 ; 1.2327]$} & 0.4068 \\
\hline & $\mathrm{CH}$ & 1 & 0.82 & {$[0.2948 ; 2.2927]$} & 0.7082 \\
\hline & DN & 4 & 1.02 & {$[0.8306 ; 1.2477]$} & 0.8635 \\
\hline \multirow[t]{5}{*}{ pairw3 (Aa vs. aa) } & Overall & 13 & 1.03 & {$[0.7832 ; 1.3445]$} & 0.8515 \\
\hline & ESRD & 2 & 1.06 & {$[0.5720 ; 1.9761]$} & 0.8464 \\
\hline & $\mathrm{NL}$ & 6 & 0.79 & {$[0.4507 ; 1.3857]$} & 0.4113 \\
\hline & $\mathrm{CH}$ & 1 & 2.30 & {$[0.8331 ; 6.3500]$} & 0.1080 \\
\hline & DN & 4 & 1.10 & {$[0.8688 ; 1.3802]$} & 0.4417 \\
\hline
\end{tabular}

\section{Funding}

The authors extend their appreciation to the Deanship of Scientific Research at King Saud University for funding the work through the research group project No. RG-1439-74.

Funding Role: The funding body has provided the funds for data collection and analysis and has no role in design of the study, data interpretation and manuscript writing.

\section{Availability of data and materials}

All data generated or analyzed during this study are included in this manuscript.

\section{Ethics approval and consent to participate}

Not applicable

\section{Consent for publication}

Not applicable

\section{Competing interests}

The authors declare that they have no competing interests.

\section{Author details}

${ }^{1}$ Center of Excellence in Biotechnology Research, Department of Biochemistry, College of Science Building 5, King Saud University, Riyadh 11451, Saudi Arabia. ${ }^{2}$ Biochemical Genetics, Sandor Life Sciences Pvt. Ltd, Hyderabad, India. ${ }^{3}$ Department of Biochemistry, College of Science, King Saud University, Riyadh, Saudi Arabia.

Received: 29 August 2019 Accepted: 28 November 2019

Published online: 10 December 2019

\section{References}

1. Bikle DD. Vitamin D metabolism, mechanism of action, and clinical applications. Chem Biol. 2014;21(3):319-29. 
2. Ogunkolade BW, Boucher BJ, Prahl JM, Bustin SA, Burrin JM, Noonan K, North BV, Mannan N, McDermott MF, DeLuca HF, et al. Vitamin D receptor (VDR) mRNA and VDR protein levels in relation to vitamin D status, insulin secretory capacity, and VDR genotype in Bangladeshi Asians. Diabetes. 2002; 51(7):2294-300.

3. Chandel N, Ayasolla K, Wen H, Lan X, Haque S, Saleem MA, Malhotra A, Singhal PC. Vitamin D receptor deficit induces activation of renin angiotensin system via SIRT1 modulation in podocytes. Exp Mol Pathol. 2017;102(1):97-105.

4. Yang L, Wu L, Fan Y, Ma J. Associations among four polymorphisms (Bsml, Fokl, Taql and Apal) of vitamin D receptor gene and end-stage renal disease: a meta-analysis. Arch Med Res. 2015;46(1):1-7.

5. Yang $L$, Wu L, Fan $Y$, Ma J. Vitamin D receptor gene polymorphisms in association with diabetic nephropathy: a systematic review and metaanalysis. BMC Med Genet. 2017;18(1):95.

6. Zhou TB, Jiang ZP, Huang MF. Association of vitamin D receptor Bsml (rs1544410) gene polymorphism with the chronic kidney disease susceptibility. J Recept Signal Transduct Res. 2015;35(1):54-7.

7. Nosratabadi R, Arababadi MK, Salehabad VA, Shamsizadeh A, Mahmoodi M, Sayadi AR, Kennedy D. Polymorphisms within exon 9 but not intron 8 of the vitamin $D$ receptor are associated with the nephropathic complication of type-2 diabetes. Int J Immunogenet. 2010;37(6):493-7.

8. Liu W, Chen M, Li M, Ma H, Tong S, Lei Y, Qi L. Vitamin D receptor gene (VDR) polymorphisms and the urolithiasis risk: an updated meta-analysis based on 20 case-control studies. Urolithiasis. 2014;42(1):45-52.

9. Zhang $P$, Nie $W$, Jiang $H$. Effects of vitamin $D$ receptor polymorphisms on urolithiasis risk: a meta-analysis. BMC Med Genet. 2013;14:104.

10. Yin F, Liu J, Fan MX, Zhou XL, Zhang XL. Association between the vitamin D receptor gene polymorphisms and diabetic nephropathy risk: a metaanalysis. Nephrology (Carlton). 2018;23(2):107-16.

11. Liu Z, Liu L, Chen X, He W, Yu X. Associations study of vitamin D receptor gene polymorphisms with diabetic microvascular complications: a metaanalysis. Gene. 2014;546(1):6-10.

12. Matana A, Popovic M, Torlak V, Punda A, Barbalic M, Zemunik T. Effects of genetic variants on serum parathyroid hormone in hyperparathyroidism and end-stage renal disease patients: a systematic review and meta-analysis. Medicine (Baltimore). 2018;97(21):e10834.

13. Guha M, Bankura B, Ghosh S, Pattanayak AK, Ghosh S, Pal DK, Puri A, Kundu AK, Das M. Polymorphisms in CaSR and CLDN14 genes associated with increased risk of kidney stone disease in patients from the eastern part of India. PLoS One. 2015;10(6):e0130790.

14. Han RDX, Su B, Yang W, Liu H, Song D. Association between Taql, Apal of vitamin $D$ receptor gene polymorphism and type 2 diabetic nephropathy of the Han nationality in Kunming. Chin Med Herald. 2015;12(9):69-72.

15. Goknar N, Oktem F, Torun E, Gok O, Demir AD, Kucukkoc M, Kilic U. The role of vitamin D receptor gene polymorphisms in Turkish infants with urolithiasis. Ren Fail. 2016;38(4):545-51.

16. Ozkaya O, Soylemezoglu O, Misirlioglu M, Gonen S, Buyan N, Hasanoglu E. Polymorphisms in the vitamin D receptor gene and the risk of calcium nephrolithiasis in children. Eur Urol. 2003;44(1):150-4

17. Gunes $\mathrm{S}$, Bilen $\mathrm{CY}$, Kara N, Asci R, Bagci H, Yilmaz AF. Vitamin D receptor gene polymorphisms in patients with urolithiasis. Urol Res. 2006;34(1):47-52.

18. Seyhan S, Yavascaoglu I, Kilicarslan H, Dogan HS, Kordan Y. Association of vitamin D receptor gene Taq I polymorphism with recurrent urolithiasis in children. Int J Urol. 2007;14(12):1060-2.

19. Aykan S, Tuken M, Gunes S, Akin Y, Ozturk M, Seyhan S, Yuruk E, Temiz MZ, Yilmaz AF, Nguyen DP. ApaL1 urokinase and Taq1 vitamin D receptor gene polymorphisms in first-stone formers, recurrent stone formers, and controls in a Caucasian population. Urolithiasis. 2016;44(2):109-15.

20. Cakir OO, Yilmaz A, Demir E, Incekara K, Kose MO, Ersoy N. Association of the Bsml, Apal, Taql, Tru9l and Fokl polymorphisms of the vitamin D receptor gene with nephrolithiasis in the Turkish population. Urol J. 2016; 13(1):2509-18

21. Tripathi G, Sharma R, Sharma RK, Gupta SK, Sankhwar SN, Agrawal S. Vitamin $D$ receptor genetic variants among patients with end-stage renal disease. Ren Fail. 2010;32(8):969-77.

22. Mittal RD, Mishra DK, Srivastava P, Manchanda P, Bid HK, Kapoor R. Polymorphisms in the vitamin $\mathrm{D}$ receptor and the androgen receptor gene associated with the risk of urolithiasis. Indian J Clin Biochem. 2010;25(2): $119-26$.
23. Wang LY, Zhang P, Wang HF, Qin ZW, Wei KB, Lv XA. Association of vitamin $D$ receptor gene polymorphisms with end-stage renal disease and the development of high-turnover renal osteodystrophy in a Chinese population. Genet Mol Res. 2016;15(2)

24. Martin RJ, McKnight AJ, Patterson CC, Sadlier DM, Maxwell AP, Warren UKGSG. A rare haplotype of the vitamin D receptor gene is protective against diabetic nephropathy. Nephrol Dial Transplant. 2010;25(2):497-503.

25. Mossetti G, Vuotto P, Rendina D, Numis FG, Viceconti R, Giordano F, Cioffi M, Scopacasa F, Nunziata V. Association between vitamin D receptor gene polymorphisms and tubular citrate handling in calcium nephrolithiasis. J Intern Med. 2003;253(2):194-200.

26. Moyano MJ, Gomez de Tejada MJ, Garcia Lozano R, Moruno R, Ortega R, Marti V, Sanchez Palencia R, Miranda MJ, Palma A, Perez Cano R. Alterations in bone mineral metabolism in patients with calcium kidney stone disease and polymorphism of vitamin D receptor. Preliminary results. Nefrologia. 2007;27(6):694-703.

27. Bucan K, Ivanisevic M, Zemunik T, Boraska V, Skrabic V, Vatavuk Z, Galetovic D, Znaor L. Retinopathy and nephropathy in type 1 diabetic patients-association with polymorphysms of vitamin D-receptor, TNF, Neuro-D and IL-1 receptor 1 genes. Coll Antropol. 2009;33(Suppl 2):99-105.

28. Zhang H, Wang J, Yi B, Zhao Y, Liu Y, Zhang K, Cai X, Sun J, Huang L, Liao Q. Bsml polymorphisms in vitamin $D$ receptor gene are associated with diabetic nephropathy in type 2 diabetes in the Han Chinese population. Gene. 2012;495(2):183-8.

29. Ghorbanihaghjo A, Argani H, Samadi N, Valizadeh S, Halajzadeh J, Yousefi B, Rashtchizadeh N. Relationship between vitamin D receptor gene Fokl and Apal polymorphisms and serum levels of fetuin-A, vitamin D, and parathyroid hormone in patients on hemodialysis. Iran J Kidney Dis. 2014; 8(5):394-400.

30. Singh PK, van den Berg PR, Long MD, Vreugdenhil A, Grieshober L, OchsBalcom HM, Wang J, Delcambre S, Heikkinen S, Carlberg C, et al. Integration of VDR genome wide binding and GWAS genetic variation data reveals cooccurrence of VDR and NF-kappaB binding that is linked to immune phenotypes. BMC Genomics. 2017;18(1):132

31. Tian Y, Lv G, Yang Y, Zhang Y, Yu R, Zhu J, Xiao L, Zhu J. Effects of vitamin $D$ on renal fibrosis in diabetic nephropathy model rats. Int J Clin Exp Pathol. 2014;7(6):3028-37.

32. Cinar N, Harmanci A, Yildiz BO, Bayraktar M. Vitamin D status and seasonal changes in plasma concentrations of 25 -hydroxyvitamin $D$ in office workers in Ankara, Turkey. Eur J Intern Med. 2014;25(2):197-201.

33. Leary PF, Zamfirova I, Au J, McCracken WH. Effect of latitude on vitamin D levels. J Am Osteopath Assoc. 2017;117(7):433-9.

\section{Publisher's Note}

Springer Nature remains neutral with regard to jurisdictional claims in published maps and institutional affiliations.
Ready to submit your research? Choose BMC and benefit from:

- fast, convenient online submission

- thorough peer review by experienced researchers in your field

- rapid publication on acceptance

- support for research data, including large and complex data types

- gold Open Access which fosters wider collaboration and increased citations

- maximum visibility for your research: over $100 \mathrm{M}$ website views per year

At BMC, research is always in progress.

Learn more biomedcentral.com/submission 